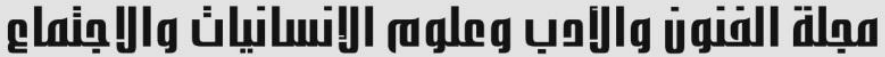

Journal of Arts, Literature, Humanities and Social Sciences www.jalhss.com

\section{The Impact of Multimedia Super Corridor (MSC) on Malaysian Economic Growth}

\author{
Dr. Khattab Imran Saleh \\ Tikrit University- Iraq \\ Email: khatabomran@yahoo.com
}

Farhan Abdulrahman Kheder

Ministry of Education- Iraq

Email: juborifarhan@gmail.com

Assist. Prof. Nzhan Mohammed Sahoo

University of Sammarra - Iraq

Email: nazhanalsaho@gmail.com

\begin{abstract}
The study aimed to illustrate the concepts of Multimedia Super Corridor (MSC) ، show it's positive and negative impact in general, its barriers and some of its economic impacts sparticularly on economic growth 'the local capital and employment in the Malaysian economy. the researcher used the analytical descriptive method through the presentation of the previous studies and using some indicators from international institutions. The study comes up with several inclusions such as (MSC) is considered an important component of investment attraction strategy with high benefits on the Malaysian economy, especially in economic growth, provision of foreign inflows, job creation, transferring technology and infrastructure development. The study showed that MSC in Malaysia has contributed significant value to national GDP with a cumulative of RM 34.57 billion in phase two.
\end{abstract}

Keywords: Economic Growth, Multimedia Super Corridor, Malaysian Economy. 


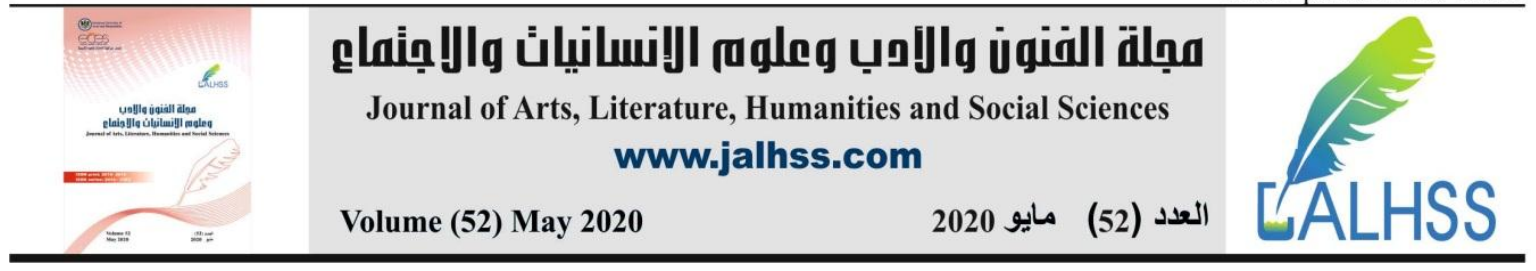

\section{Introductions:}

There is no doubt that information and communication technologies (ICT) have an important impact on most countries in the world, it affects the communication and the way of working, also ICT is one of the important sectors that forming knowledgebased economy as it facilitates the transformation of information and technology through different sectors of the economy.

Samuelson \& Nurdhaus defined Economic growth as " Economic growth involves the growth of potential output over the long run. The growth in output per capita is an important objective of government because it is associated with rising average real incomes and rising living standards"'(Samuelson \& Nurdhaus, 2010, p501). Which means the increase in the production of goods and services which can be improved using the information and communication technology (ICT), ICT will help in decreasing the time of the production also save more efforts as we will use developed machines in the production cycle also it will help in delivering the service to the customer efficiently.

Information and communication technology (ICT) also is an important engine of Economic growth as it positively affects investment, trade, treasury, Employment and GDP.

The Multimedia Super Corridor (MSC) in Malaysia refers to Malaysia's plans, efforts, and foundations that focus on the creation of a high-tech environment that aims to encourage and attract international investors to open their ITC companies in Malaysia benefiting from (world number one information and Technology infrastructure and environment, with attractive financial services and incentives) and create a multiplier effect in the Malaysian economy. Since 1996, Malaysia MSC was the most exciting initiative for the global information and communication technology (ICT) industry, with this unique corridor, Malaysia continues to attract leading ICT companies of the world to locate their industries in the MSC and undertake research, develop new products and technologies and export from this base.

\section{Research Problem:}

To enhance the development of the ICT industry and promote a knowledgebased economy in Malaysia; the MSC Malaysia was established to become a global hub for ICT and to push the Malaysian economy up to the higher value chain, through technology-intensive and knowledge economy.

MSC Malaysia has played a significant role and gave a great impact on the national economy in terms of local revenue, export, employment and R\&D.

\section{Research Hypotheses:}

1. The Multimedia Super Corridor (MSC) is Malaysia's most exciting initiative for the global information and communication technology (ICT) industry.

2. MSC Malaysia has an important contribution to the Malaysian economic growth. 


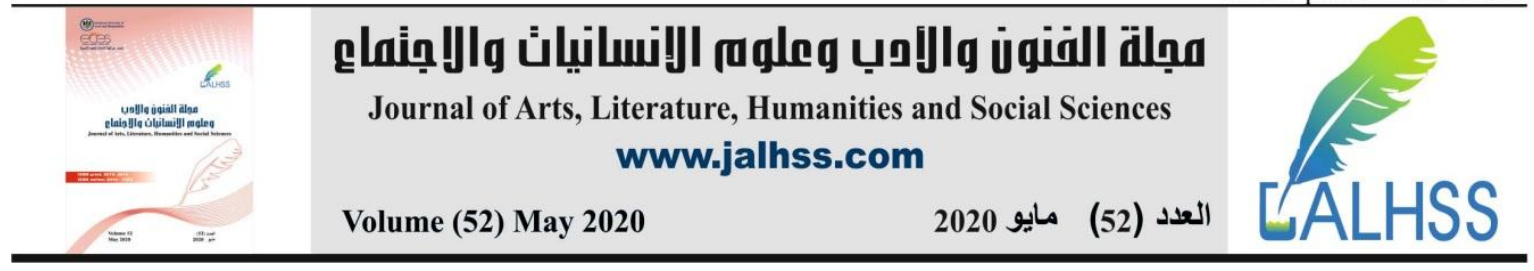

\section{The objectives:}

1. To describe the achievement and contribution of MSC Malaysia in the Malaysian economy.

2. To evaluate the MSC Malaysia's contribution in the Malaysian economy and give some recommendations for its continuing relevance in driving the economy.

\section{First Section: The development of MSC Malaysia:}

\section{Introduction}

Malaysia set the foundation of the knowledge economy by facilitating human development, science and technology and research and development.

Malaysia started to lay the foundation for the knowledge-based economy in the mid-1990s by launching the National IT Agenda (MITA) and the Multimedia Super Corridor (MSC). The Multimedia Super Corridor (MSC) was launched by the Malaysian Government in 1996 under the supervision of Dr. Mahathir Mohammad, to develop the ICT in Malaysia. (Kheong 2009, p.30

MSC consists of four major large projects known as the Kuala Lumpur City Center (ICLCC), Kuala Lumpur International Airport (KLIA), Putrajaya and Cyberjaya (two of the global Smart Cities), it includes Multimedia industries, R\&D centers, a multimedia university, shared services and outsourcing centers and Technology Park Malaysia. (Injau,2011, p 2)

The Multimedia Development Corporation (MDEC) was established to take charge of the development and implementation of MSC.

MSC Malaysia offers many benefits to encourage investment in MSC like ICT infrastructure. Freedom of ownership, financial incentives, competitive cost and the protection of the property right.

Firsts: The development of the MSC Malaysia (https://mdec.my/)

The development of the MSC Malaysia is planned under three phases as per the following

The first phase of development (1996-2003):

This phase includes the foundation of the ICT infrastructure, two smart cities are created, cyber laws layout was issued, about 22,000 jobs created and it achieved a revenue of RM6 billion.

The second phase of development (2004-2010);

This phase includes connecting the cities in MSC with other cities in Malaysia and with other cyber cities of the world, the number of MSC companies and jobs (100,000 jobs), also around 1400 property right is granted

The third phase of development (2011-2020):

This phase aims to Link all Malaysia to the whole world by expanding the ICT connection, to include 500 companies in ICT, the first cyber court established and to build up to 12 smart cities.

Second: MSC Malaysia Achievements and Milestones (Target and actual) the following table shows the MSC Malaysia achievements 


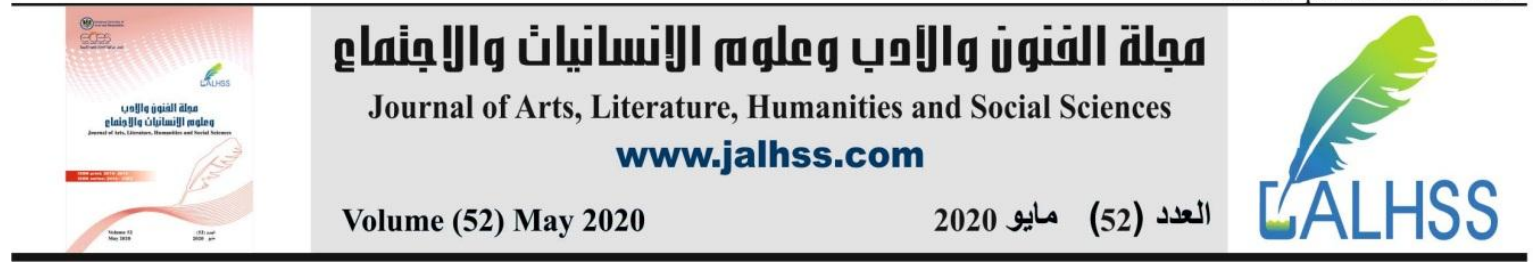

Table 1: MSC Malaysia Achievements and Milestones (Target and actual)

Phase I ( 1996 - 2003 ) target

1 corridor

50 world-class local companies

Launch 7 flagship applications

a framework of cyber laws

Cyberjaya as a world-leading intelligent city with a balanced

Phase II ( 2004 - 2010 ) target

Web of corridors

3,750 MSC Malaysia status and 250 MSC

Malaysia global companies

Enhance flagships application and introduce new ones

Leadership towards a harmonized global framework of cyber laws
Achievements

A corridor ranging from KLCC to KLIA, including Cyberjaya and Putrajaya, created

742 companies, 50 foreign and local MNCs , awarded MSC status

All 7 flagship applications were launched

set of cyber-laws were enacted

Investments in Cyberjaya were focused on physical infrastructure while the development of social infrastructure was not at the same pace

\section{Achievements}

7 Cyber-cities and 8 Cyber-centers have been rolled out

By end 2007 - 1,482 MSC status companies 17 are Strong Performers and 84 are MNCs

Flagship applications have yet to realize their full potential. There have been no new flagships.

ICT-related laws (especially IP- protection rights) have yet to be adequately enforced
Enhance the local ICT industry and catalyze potential world-class local companies
By end 2007 - 1,100 local MSC status companies and 17 Strong Performers

High-speed link connectivity to Japan, Europe, Asia Pacific, and the US is now available with outbound bandwidth at $27 \mathrm{Gbps}$ and further improvements planned
Link to world-leading intelligent cities Highspeed link connectivity to Japan, Europe,

Source: Malaysia National IT Council (www.nitc.org.my).

\section{Third: MSC Malaysia driving factors} Cyber-cities and Cyber-centers

MSC developed the cyber cities and centers to attract investment in MSC especially in Knowledge-based industries. There are 16 Cyber-cities and Cybercenters across the country; 10 in the Klang Valley and 6 in other states of Peninsular Malaysia. (World Bank, 2018,pp.10-13)

Qualifying Criteria. ( https://mdec.my)

For the qualifying criteria, the MSC qualifying activities are categorized under three (3) main clusters.

1. Software \& e-solution.

2. Shared services \& outsourcing. 


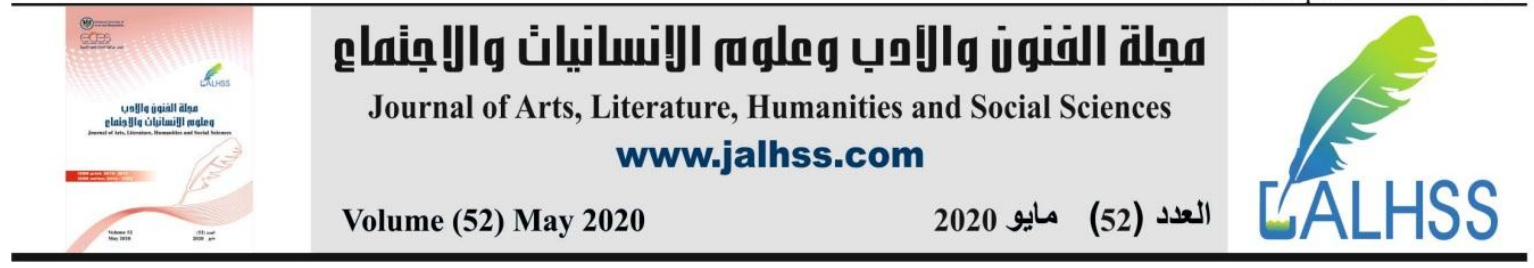

3. Creative multimedia. To qualify for MSC-Malaysia Status, there are some criteria are:

Companies must work in the information technology field or its products, appoint a large number of the knowledge workers, and clarify the importance of its company and the value added to the Malaysian economy and follow Malaysia's guidelines.(https://mdec.my/).

\section{3. e-Xpats Centre \& e-Dfi System}

E-Xpats center is an online system to develop the services that delivered to the companies in MSC and ensure its efficiency.

E-Dfi system (Electronic ' Duty-Free Importation system) is an online system that used to link the companies in MSC to related agencies; it also provides other services for the companies such as Bill of grantees.( (Injau,2011, pp. 12-13)

\section{Intellectual Property}

Intellectual Property Corporation of Malaysia was established to effectively administer the intellectual property, trademarks, patents, industrial design, and copyrights, enforce the intellectual property laws, aware citizens of the importance of the property rights, and help companies to protect their property rights.

The Malaysian government grants the IP incentives for the companies who fill the application regarding the protection of their property rights these incentives up to $70 \%$ of the initial cost for filing applications to register the property rights protection. (http://www.myipo.gov.my/ )

\subsection{MSC Flagship Applications}

To link the Malaysian economy with MSC Malaysia a various MSC Flagship Application projects were established they are: (Saleh,2004, pp. 186-187)

\section{E-Government}

It is a software application that provides the citizens with the services and information to satisfy their needs, this application will improve the information flow between the government and the public, cost and time savings and will increase the feedback with High quality services.

\section{Multipurpose Card}

To secure the private and government transaction the government issued the Multipurpose Cards, these cards are cost-saving and reduce the use of paper.

\section{Smart School}

To encourage creativity and solve the issue of illiteracy the government adopted the concept of smart schools by upgrading the infrastructure, software application and supports the teachers to use ICT.

\section{Telehealth}

To improve the healthcare of the people using many programs like Teleconsultation, My Health portal and Lifetime Health Record.

3.5 Bill of Guarantees (BoGs) (http://www.rnyipo.gov.my/)

Companies that are granted the MSC-Malaysia status enjoy the 10 Bill of Guarantees (BoGs), which include: 


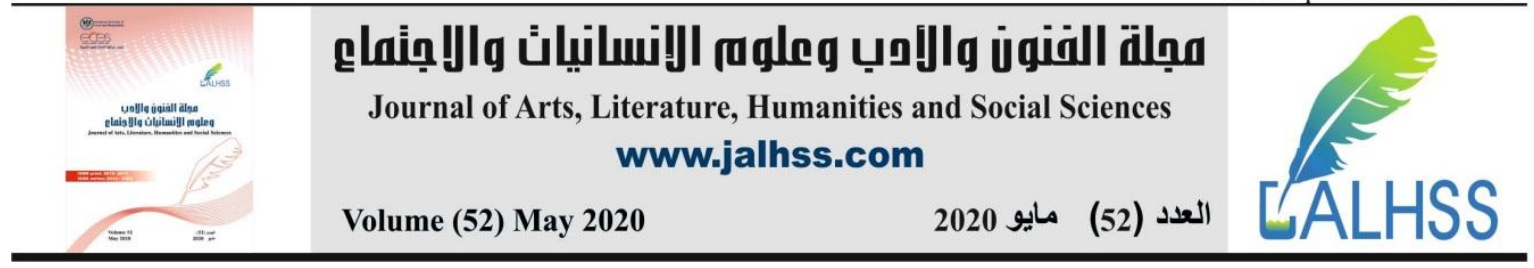

1. Provide a world-class physical and information infrastructure: Malaysia will provide the companies with the infrastructure, researches, new technologies and applications that will enable them to operate their business.

2. Unrestricted employment of local and foreign knowledge workers:

MSC Malaysia employs many knowledge workers.

3. Ensure freedom of ownership:

MSC Malaysia Status companies are exempted from equity conditions and paid-up capital conditions.

4. Give the freedom to fund their companies globally, and the freedom to repatriate the profits and dividends form the investment in MSC companies.

5. Provide competitive financial incentives such as investment tax allowance and no duties on the import of multimedia equipment.

6. To be protected by a regulatory framework such as intellectual property law and other cyber laws and to ensure that these laws will be enforced.

7. Ensure no Internet crimes as the relevant ministries and agencies will take any action regarding any illegal activity in the online environment.

8. Provide globally competitive telecommunications tariffs that will suit the overall economic conditions and telecommunications framework of the Country.

9. Set deals with the leading Companies that willing to use MSC Malaysia as their regional hub and offer many incentives for these companies to encourage them to invest in the infrastructure.

10. To establish an agency that responsible for the development of MSC Malaysia such as Multimedia Development Corporation (MDEC) which facilitates the interaction between the companies and the governmental agencies.

First: According to figures blew, the total number of Malaysian MSC companies increased from 426 in 2000 to 3403 in 2013, in2013. 236 new companies were established with an annual increase rate reached (7.5\%) with total investment reached 3 MR Billions ( $22 \%$ from foreign direct investment).

First: According to figures blew, the total number of Malaysian MSC companies increased from 426 in 2000 to 3403 in 2013, in2013. 236 new companies were established with an annual increase rate reached (7.5\%) with total investment reached 3 MR Billions ( $22 \%$ from foreign direct investment. (Anna, 2009, pp. 16-18) 


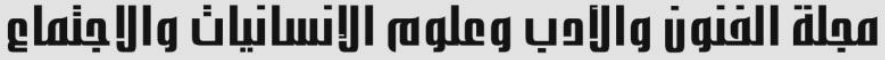

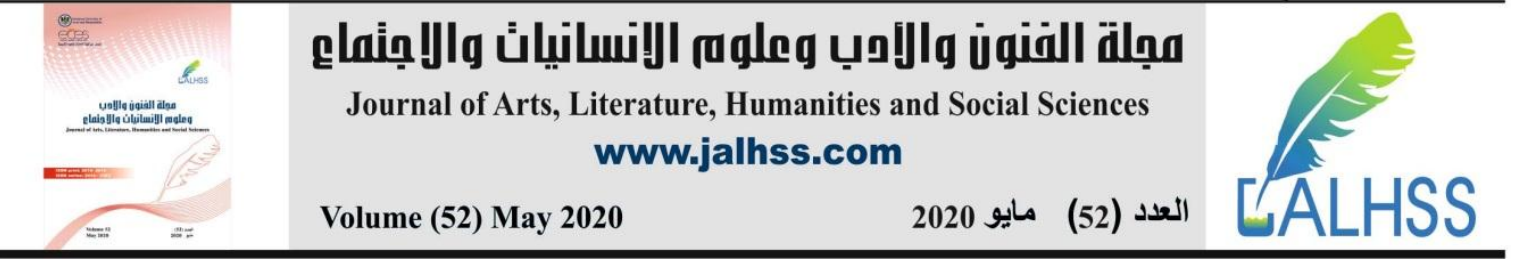

Figure 1: Malaysian MSC Companies Growing (2000 - 2013).

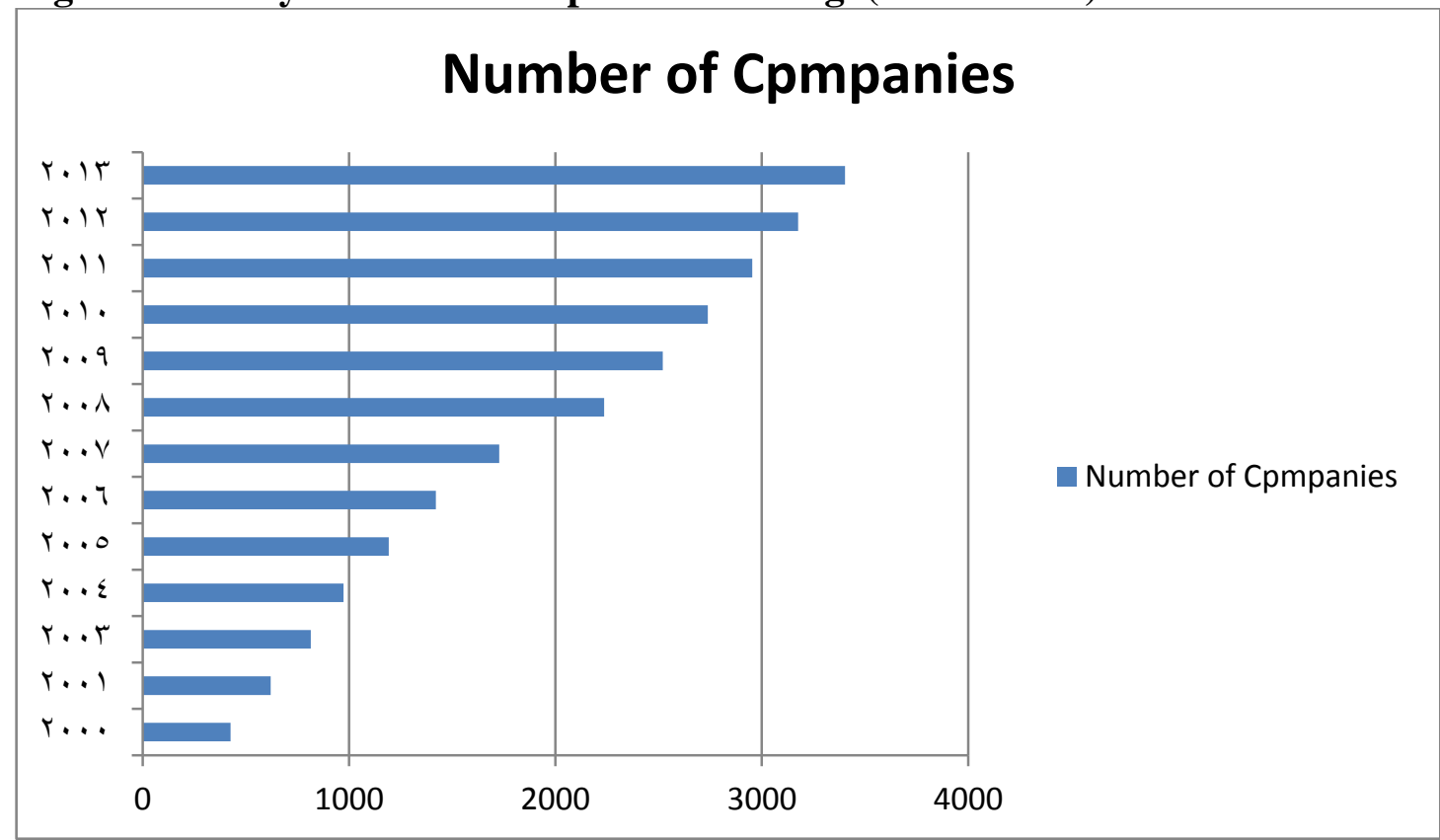

Source: MSC Malaysia annual industry report, MDEC, 2013.

Figure 2: Malaysia MSC companies by technology poster 2013

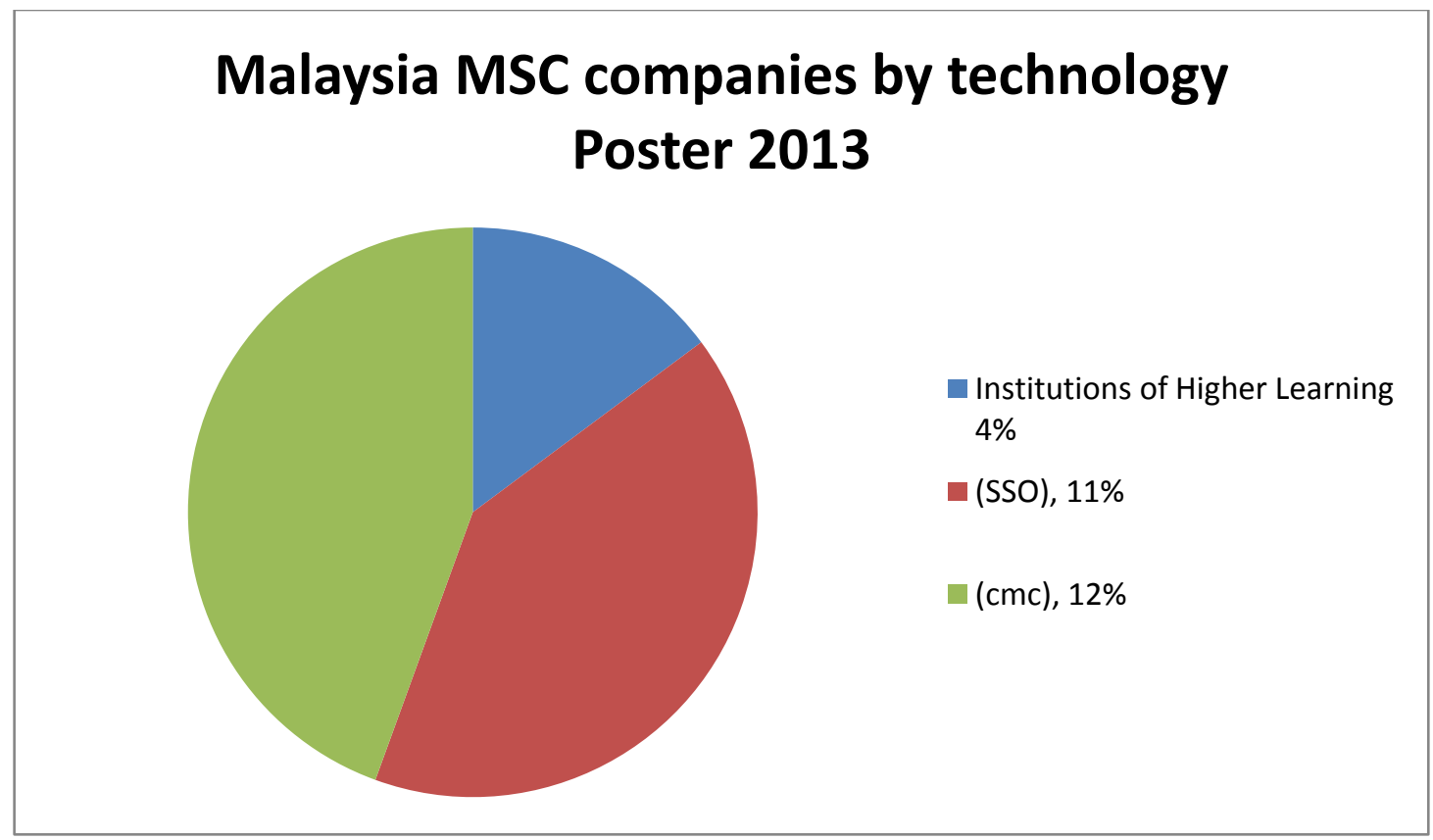

Source: MSC Malaysia annual industry report, MDEC, 2013.Second: Malaysia MSC companies' Investment, 2013. 


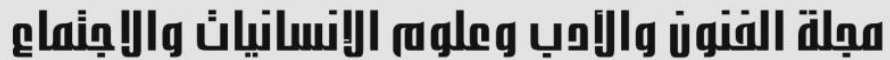

Journal of Arts, Literature, Humanities and Social Sciences www.jalhss.com

\section{Second: Malaysia MSC companies' Investment, 2013.}

The investment strategy in MSC based on low cost as a competitive advantage but it focuses on the companies that their business related to the following sectors: Shared Services \& Outsourcing (SSO). Software \& e-Solutions and Creative Multimedia (CMC) as the Malaysian government supports them with more investment (Kheong, 2009, P. 30).

Malaysia MSC companies' Investment reached to RM 3 Billion in 2013 Classified as the following figure:

Figure 3: Malaysia MSC companies' Investment Development 2013.

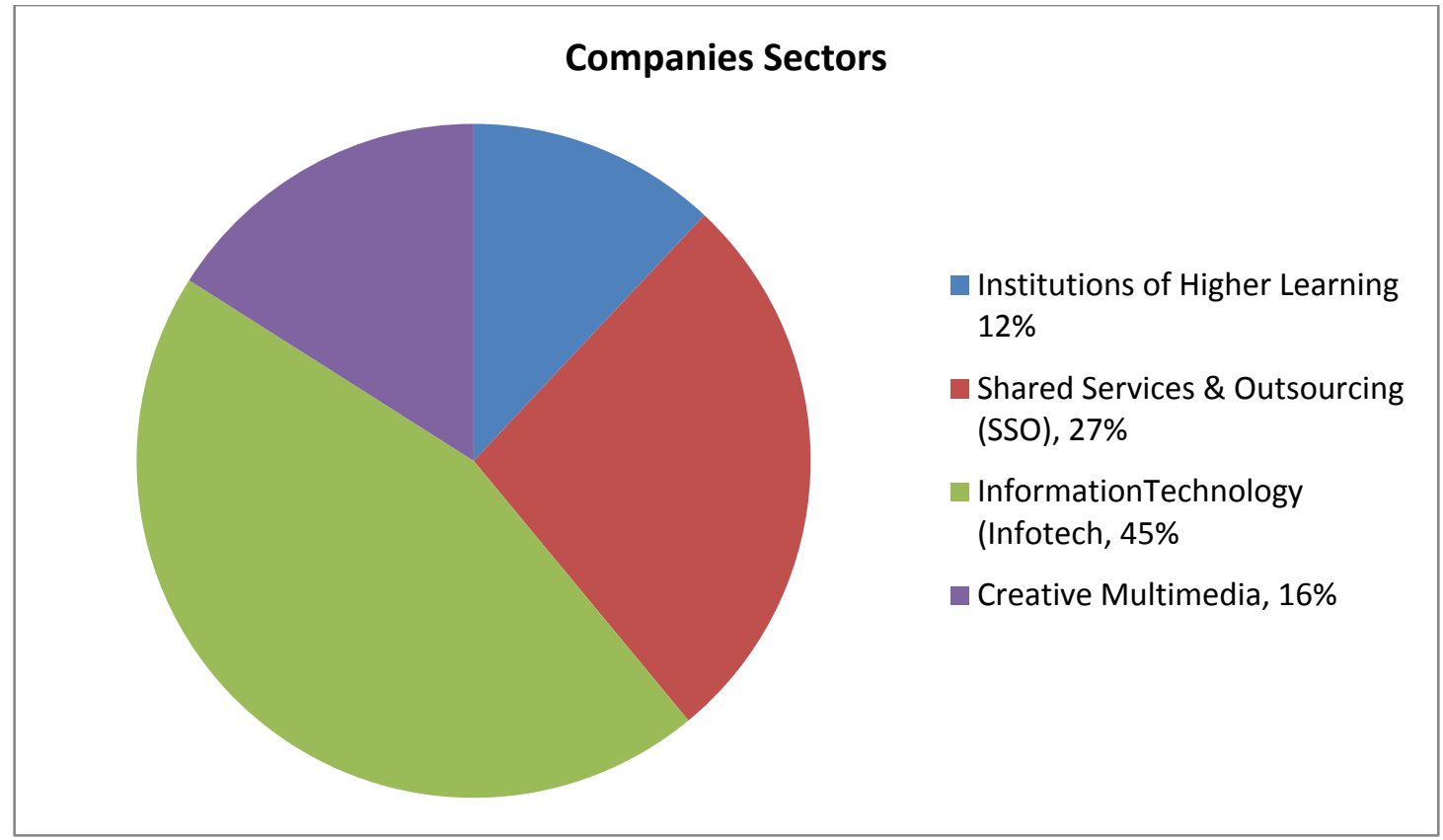

Source: MSC Malaysia annual industry report, MDEC, 2013

\section{Third: Malaysia MSC companies' Revenues}

in 2013. the Malaysia MSC companies contributed to the total revenues with 34.55 Billion in 2013 with an annual increase of $1 \%$ of 2012 (33.53\%). The Info-Tech cluster recorded the highest revenue representing 41\% of total MSC revenues in 2013 followed by Shared service \&outsourcing (SSO) $37 \%$ while creative multimedia (CMC) representing $18 \%$ and the Institutions of higher learning representing $4 \%$. 


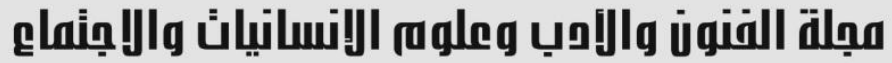

Journal of Arts, Literature, Humanities and Social Sciences www.jalhss.com

Figure 4: Malaysia MSC companies' Revenues (2009-2013)

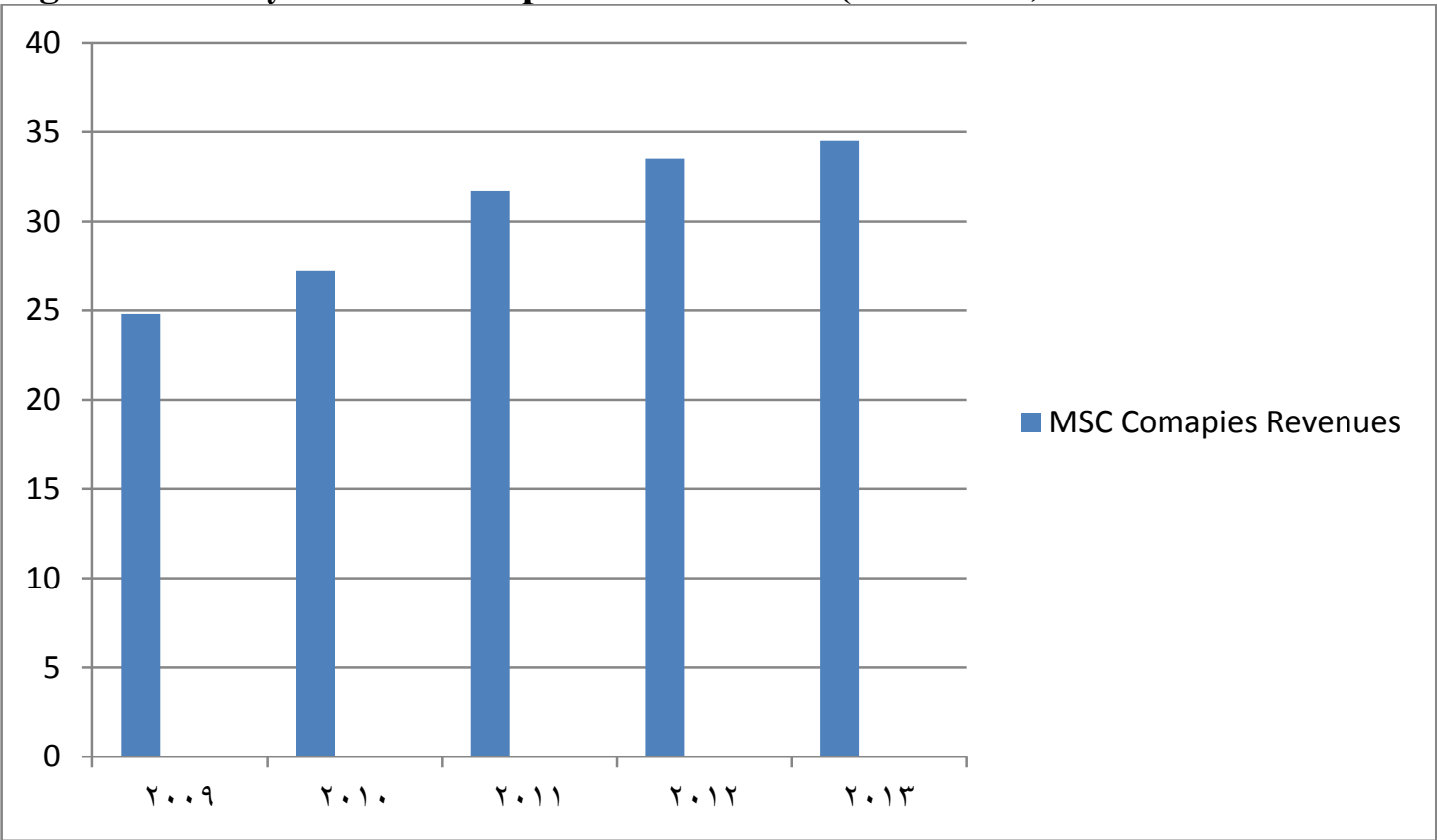

Source: MSC Malaysia annual industry report, MDEC, 2013.

\section{Fourth: Malaysia MSC companies' Exports}

Total MSC Malaysia exports in 2013 increased by 7.4\% from 2012; the highest contributor to the exports is Shared service \&outsourcing (SSO) representing 68\%. The Info-Tech cluster recorded 28\% of total MSC exports in 2013, creative multimedia (CMC) representing $3 \%$ and the Institutions of higher learning representing $1 \%$.

Figure 5: Malaysia MSC Local sales and Export sales (RM Billion), 2013 


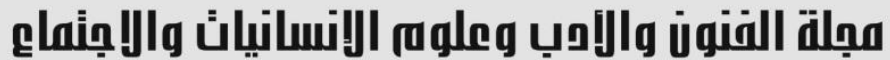

Journal of Arts, Literature, Humanities and Social Sciences www.jalhss.com

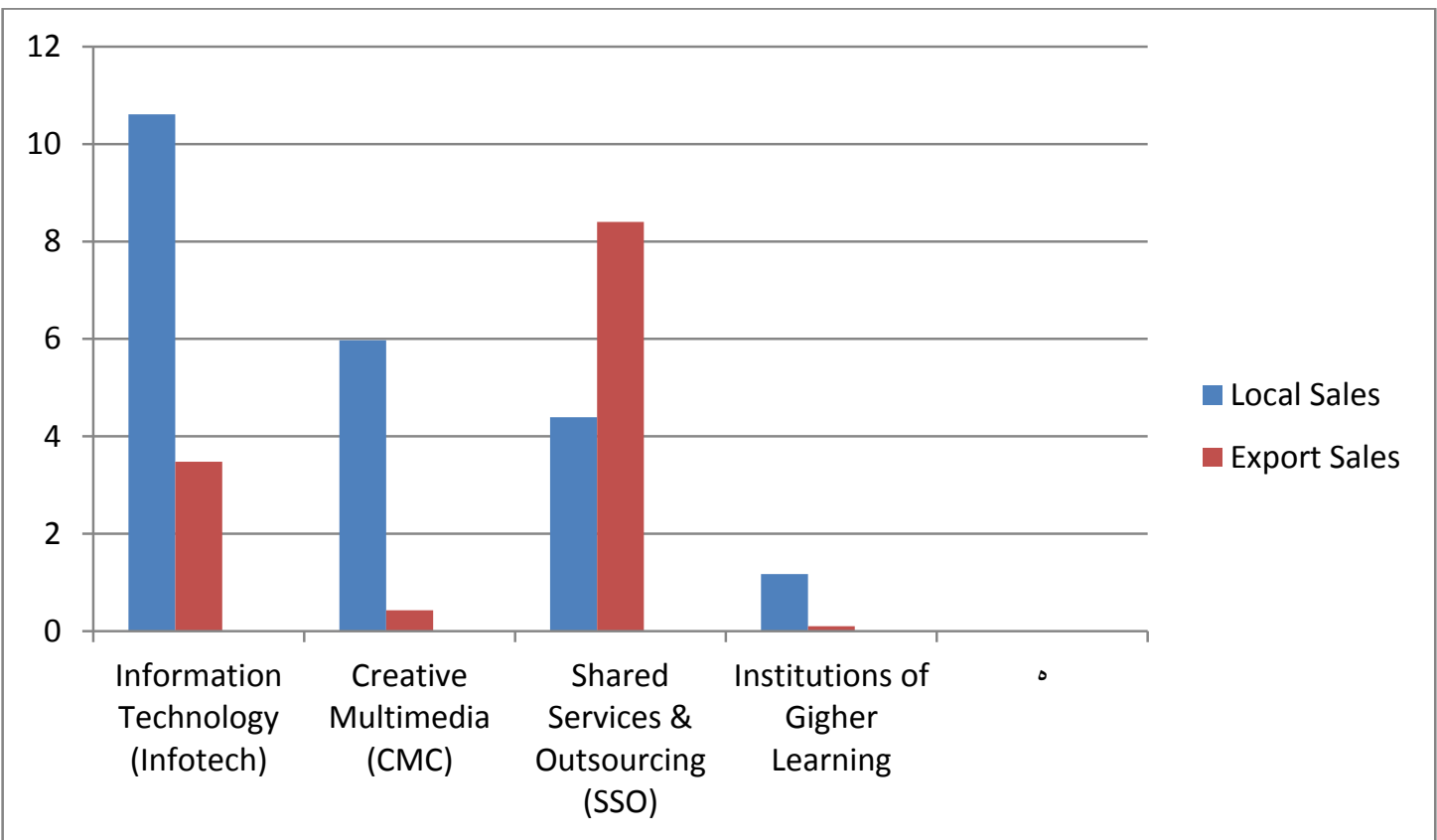

Source: MSC Malaysia annual industry report, MDEC, 2013.

\section{Fifth: Malaysia MSC Employment}

In 2013. the total jobs created in MSC companies were 138.071 with an average increase of 7.2\% from 2012 (in 2013. 9221 jobs created) also with a growth rate of $38 \%$ from 2009. this increase in knowledge workers is one of the important goals of Malaysia towards vision 2020 (knowledge economy)

The local workers in Malaysia represent $87 \%$ of the total employment in 2013. while the foreign workers represent only $13 \%$ as Malaysia needs to develop the local workforce to meet the demand in ICT Market. (The Report,2013, pp.161-162 )

Figure 6: Malaysia MSC Created Jobs by Thousands (2004-2013). 


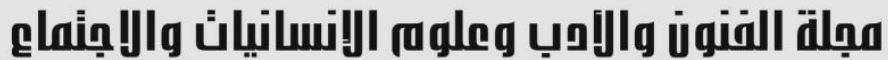

Journal of Arts, Literature, Humanities and Social Sciences www.jalhss.com

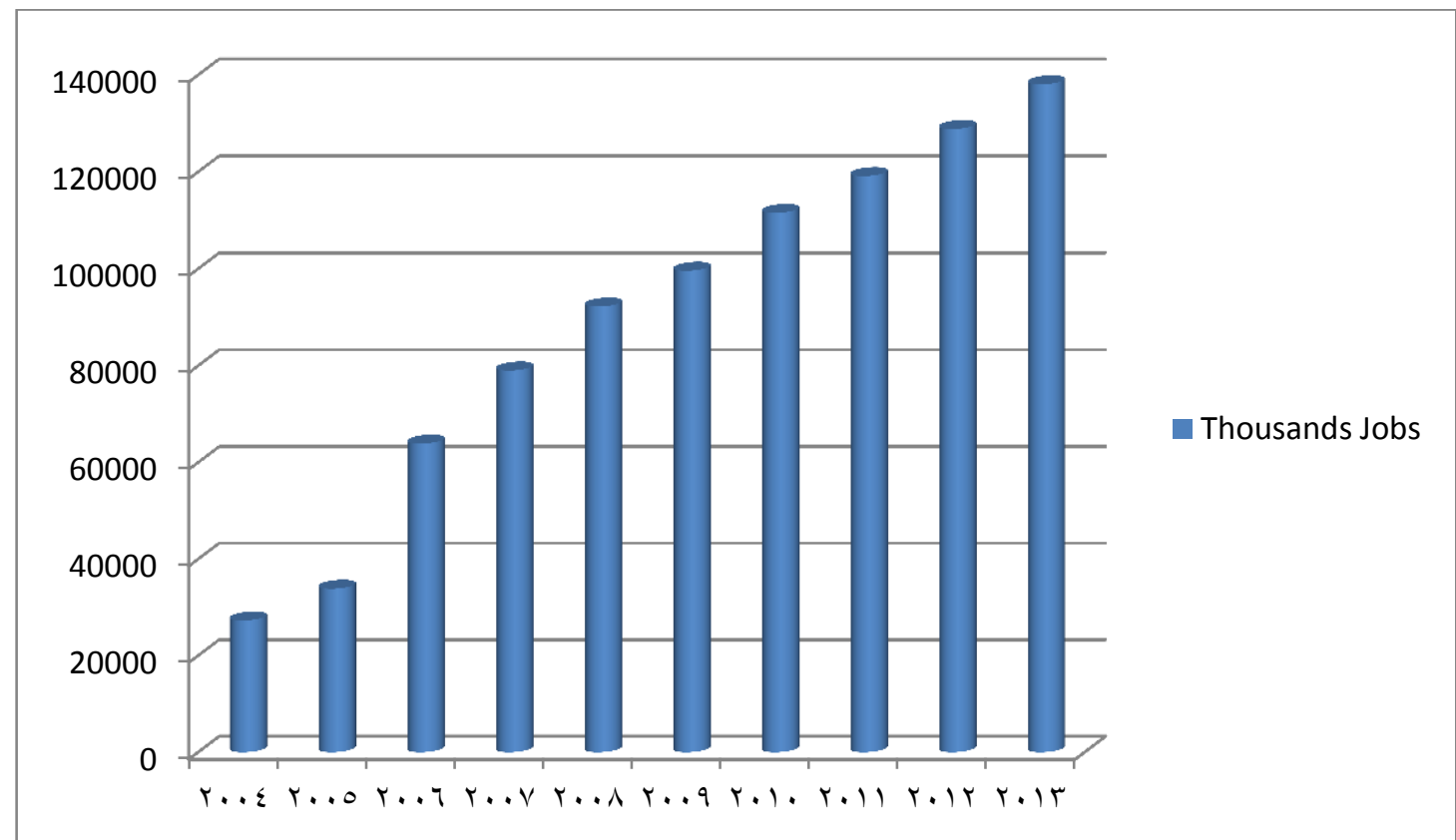

Source: MSC Malaysia annual industry report, MDEC, 2013.

Sixth: The share of MSC Status Companies and ICT Industry to GDP

ICT Industry considered one of the drivers for economic growth as its contribution to real GDP was 9.8\% in 2009 compared with $8 \%$ in 2008.

Figure 7: The Contribution of MSC Status Companies and ICT Industry to GDP (2004-2009).

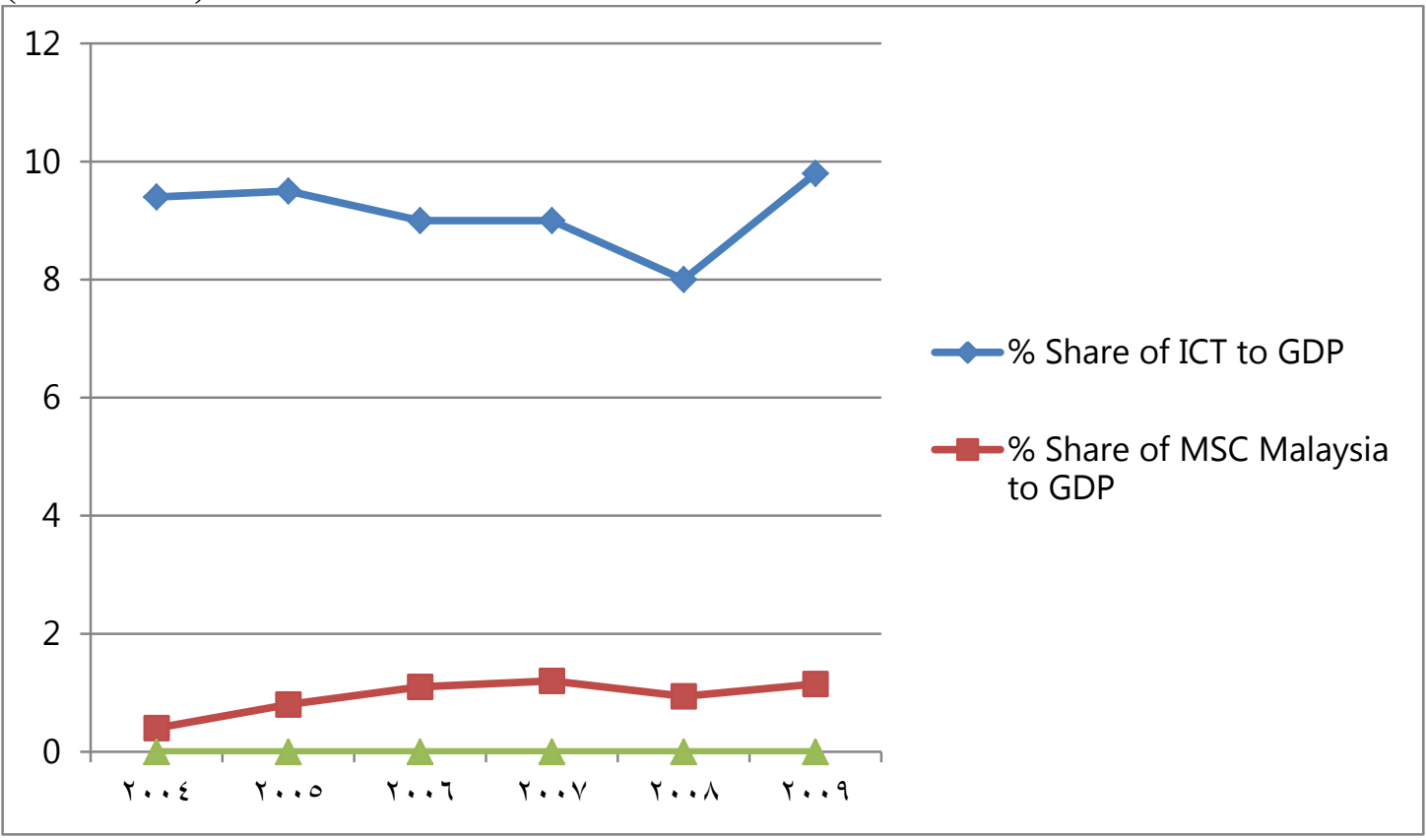

Source: (https://mdec.my/) Seminar on ICT Statistics, 2010. 


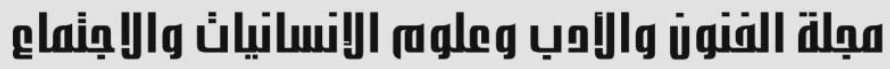 \\ Journal of Arts, Literature, Humanities and Social Sciences www.jalhss.com

\section{Conclusion:}

MSC Malaysia has a significant contribution to economic and benefited the ICT industry that will help to transform the nation into a knowledge-based economy. In terms of contribution to the economy. MSC Malaysia has contributed significant value to national GDP with a cumulative of RM 34.57 billion in phase two (2004 to 2010). Also. MSC achievements beyond contributing to the GDP. has also significant achievement with 2520 of MSC status companies producing revenue RM92.8 billion; create of 99.590 knowledge-based jobs. generated RM33.1 billion worth of exports and RM1.512 million in R\&D investment as well as Registered of 5721 new IPs.

\section{Recommendation}

1. The implementation of MSC Malaysia as a national ICT initiative should be governed by a single entity that will decide on national ICT strategies and plans and oversee the implementation of MSC Malaysia.

2. The scope of MSC Malaysia is limited to ICT companies in selected subsectors. These priority sub-sectors, namely Shared Services \& Outsourcing (SSO). Software \& e-Solutions (SeS) and Creative Multimedia (CMC) are selected based on Malaysia's current competitive advantage The scope of MSC Malaysia should be extended to include all ICT sectors, including Telco and hardware, and across the ICT value chain from manufacturing to high-end R\&D.

3. Develop HR/ talent and strengthen the national innovation system.

4. The government should also review the national R\&D incentives. 


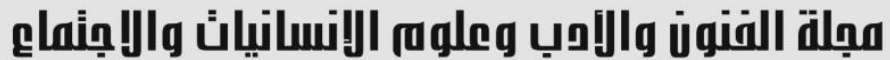

Journal of Arts, Literature, Humanities and Social Sciences

www.jalhss.com

Volume (52) May 2020

العدد (52) مايو 2020

\section{References}

1. Anna Ong \& Wein Siew Wei (2009), MSC-Malaysia Status - How Can It Benefit ICT Companies? Invest Penang, p.l.

2. Hamsha Bin Injau (2011), Evaluation of Multimedia Super Corridor (MSC Malaysia) Contribution. in Malaysian Economy, Research Report Presented to the Higher Degree Committee of Ritsumeikan, Asia Pacific University, Malaysia,p.23.

3. Jesse Chooi Tze Kheong (2009), Multimedia Super Corridor Malaysia: Publicprivate R\&D collaboration, Tech Monitor Journal, p.30.

4. Paul A. Samuelson \& William D. Nordhhaus, Economics, $19^{\text {th }}$ Edition, McGraw-Hill Publishing, Boston, 2010,p 501.

5. The Report Malaysia 2013, Oxford Business Group, pp.161-162.

6. MSC Malaysia annual industry report, MDEC, 2013.

7. Saleh, S.M. (2004), The Multimedia Super Corridor (MSC) and E-Government Initiatives in Malaysia, pp.186-187.

8.World Bank Group, (2018), Malaysia's Digital Economy, A new Driver of Development, pp. 10-13.

9. Jesse Chooi Tze Kheong (2009), Multimedia Super Corridor Malaysia: Publicprivate R\&D collaboration, Tech Monitor journal, p.30.

\section{Internet Websites}

1. Intellectual Property Corporation of Malaysia website: (http://www.rnyipo.gov.my/maklumat-korporat).

2. Malaysia Digital Economy Corporation website : https://mdec.my/ .

3. Malaysia National IT Council (www.nitc.org.my). 